DOI: https://doi.org/10.24867/07HZ04Distl

\title{
FOTOKATALITIČKA RAZGRADNJA NAPROKSENA MEŠAVINOM ZnO/TiO NANOČESTIČNOG PRAHA
}

\section{PHOTOCATALYTIC DEGRADATION OF NAPROXEN BY A MIXTURE OF ZnO/TiO NANOPARTICLE POWDER}

\author{
Vanesa Distl, Dragana Štrbac, Fakultet tehničkih nauka, Novi Sad
}

\begin{abstract}
Oblast: INŽENJERSTVO ZAŠTITE ŽIVOTNE SREDINE

Kratak sadržaj - U radu je ispitivana efikasnost fotokatalitičke razgradnje naproksena $u$ vodenoj sredini uz korišćenje fotokatalizatora na bazi mešavine $\mathrm{ZnO} / \mathrm{TiO}_{2}$ nanočestičnog praha, koji je aktiviran UV zračenjem. Rezultati ukazuju na opravdanost kombinovanja cink oksida sa titanijum dioksidom u cilju povećanja efikasnosti fotokatalitičkog procesa razgradnje naproksena $i$ otvaraju perspektivu da se nekim drugim mešavinama ovi rezultati mogu i poboljšati.
\end{abstract}

Ključne reči: naproksen, mešavina nano-prahova $\mathrm{ZnO} / \mathrm{TiO}_{2}$, fotokataliza

Abstract - In this paper, the efficiency of photocatalytic degradation of naproxen in the aqueous medium using photocatalysts based on $\mathrm{ZnO} / \mathrm{In}_{2} \mathrm{O}_{3}$ nanoparticle powder which is activated by $U V$ radiation, has been examined. The results indicates the justification of the combination of zinc oxide with titanium dioxide in order to increase the efficiency of the photocatalytic decomposition process of naproxen and opens the prospect that some other mixtures could also improve these results.

Keywords: naproxen, nanoparticle mixture $\mathrm{ZnO} / \mathrm{TiO}_{2}$, fotokataliza

\section{UVOD}

Tokom poslednje tri decenije, prisustvo farmaceutskih sredstava u životnoj sredini dobija sve veču pažnju. Odlaganje lekova u životnu sredinu je takođe povezano sa razvojem antimikrobne rezistencije, koje UN prepoznaju kao jednu od najvećih opasnosti za javno zdravlje u svetu sa kojom se suočavamo (UN Environment, 2017). Istraživanja pokazuju da nekontrolisano generisanje otpada iz farmaceutske proizvodnje ima razorni uticaj na vodene sisteme, zdravlje ljudi i zivotinja koji dolaze u kontakt sa rezistentnim bakterijama.

Lekovi i njihovi metaboliti iz različitih izvora (domaćinstva, bolnice, industrijske i gradske otpadne vode), prolaze bez dalje razgradnje kroz sisteme za prečišćavanje i kontaminiraju površinske vode. Povećana koncentracija Naproksena (NPX), čija su štetna dejstva i mogućnosti dekompozicije predmet ovog rada, može imati ozbiljne toksikološke posledice i štetan ekološki uticaj na vodene sisteme.

\section{NAPOMENA:}

Ovaj rad proistekao je iz master rada čiji mentor je bila dr Dragana Štrbac, vanr.prof.
Iz svih navedenih razloga proizilazi da je potpuno uklanjanje naproksena iz životne sredine, a posebno akvatičnih sistema, od ogromnog značaja za očuvanje čovekove okoline i zdravlja ljudi [1].

Za procese fotokatalitičke razgradnje perzistentnih polutanata koristi se čitav niz poluprovodničkih materijala i metalnih oksida, ali su najbolje fotokatalitičke osobine do sada pokazali $\mathrm{ZnO} i \mathrm{TiO}_{2}$. Prednosti cink oksida se ogledaju u visokoj efikasnsti fotokatalitičke razgradnje velikog broja farmaceutika, a titanijum dioksida u njegovoj hemijskoj stabilnosti, netoksičnosti, širokoj rasprostranjenosti i niskoj ceni [2].

\section{TEORIJSKA RAZMATRANJA}

2.1.Farmaceutici u životnoj sredini- Farmaceutski otpad je sve više prepoznatljiv kao pretnja ekosistemu i ljudskom zdravlju na globalnom nivou. Farmaceutski proizvodi mogu ući u životnu sredinu u svim faza,a njihovog životnog ciklusa(proizvodnja, upotreba, odlaganje) što znači da na kraju mogu završiti u vodi za piće i nakupljati se i u životnim namirnicama. Farmaceutska sredstva mogu se pronaći i u površinskoj vodi, otpadnim vodama, podzemnim vodama,vodi za piće, u zemljištu i drugim životnim sredinama. Klasifikacija farmaceutika je bazirana isključivo na njihovom specifičnom dejstvu, pri čemu je shodno izraženom uticaju na životnu sredinu izdvojeno sledećih osam grupa: nesteroidni antiinflamatorni lekovi, antibiotici, beta-blokatori, antiepileptici, antihistaminici, antidepresanti, hormoni i lekovi za regulaciju nivoa lipida [1].

2.2. Naproksen- Naproksen (NPX), čija su štetna dejstva i mogućnosti dekompozicije predmet ovog rada, je bela do prljavo bela lipofilna kristalna supstanca bez mirisa, čija rastvorljivost $\mathrm{u}$ vodi zavisi od $p H$ vrednosti sredine. Postojan je u vodi i u kontinuitetu detektovan u površinskim vodama širom sveta. Koeficient preraspodele oktanol/voda, pri $p H 7$ iznosi 1,6-1,8. Kao i većina nesteroidnih anti-inflamatornih lekova, on inhibira jednu ili obe forme enzima ciklo oksigenaze (COX), COX-1 ili COX-2, koji su odgovorni za formiranje važnih bioloških medijatora u organizmu, odnosno učestvuju u sintezi prostaglandina iz arahidonske kiseline. Obzirom da ribe poseduju enzim koji je sličan ljudskom COX-2, povećana koncentracija NPX može imati ozbiljne toksikološke posledice i štetan ekološki uticaj na vodene sisteme. 
Kao i većina nesteroidnih antiinflamatornih lekova i naproksen je slaba kiselina sa $p K a$ vrednošću 4,15. Nakon primene se razgrađuje u jetri, a zatim se zajedno sa produktima razgradnje vezuje za neaktivne metabolite, koji se izlučuju preko urina. $\mathrm{Ne}$ spada u lako biodegradabilna jedinjenja, ali je dokazano da se nakon faze odlaganja skoro u potpunosti razgrađuje u kontaktu sa kanalizacionim muljem.

Nakon prodiranja u životnu sredinu, do 40\% naproksena se mineralizuje veoma brzo u sedimentu površinskih voda, ali je u vodenoj sredini stabilan. Ne pokazuje tendenciju ka bioakumulaciji u vodenim životinjama.

Naproksen je detektovan $\mathrm{u}$ otpadnim vodama nakon sistema za prečišćavanje $\mathrm{i} u$ površinskim vodama $u$ koncentracijama od250 ng/1 do 1,5 $\mu \mathrm{g} / 1$ i smatra se da je efikasnost prečišćavanja u standardnim postrojenjima aproksimativno 71\%. Dodatnu zabrinutost izaziva činjenica da naproksen, kao i veliki broj drugih farmaceutika, opstaje i ostaje biološki aktivan u vodenim sredinama tokom dužeg vremenskog perioda (više od godinu dana, a moguće i do nekoliko godina), što uslovljava njegovu akumulaciju i štetan uticaj na biološke organizme.

2.3.Fotokataliza-. Fotokataliza je proces aktivacije supstanci koje modifikuju brzinu hemijskih reakcija pod dejstvom svetlosti, pri čemu one same u tim reakcijama ne učestvuju. Apsorpcijom ultraljubičastog zračenja emitovanog od strane nekog svetlosnog izvora (Sunčeva svetlost, fluorescentna lampa, LED dioda itd), elektroni iz valentne zone fotokatalizatora dovode se $\mathrm{u}$ pobuđeno stanje i prevode u provodnu zonu, ostavljajući iza sebe $u$ valentnoj zoni prazna mesta, koja se ponašaju kao pozitivno naelektrisane kvazičestice (šupljine).

Fotokatalitička aktivnost zavisi od sposobnosti katalizatora da kreira eksitone, tj. parove elektrona $\left(e^{-}\right) \mathrm{u}$ provodnoj i šupljina $\left(h^{+}\right)$u valentnoj zoni, što dovodi do stvaranja slobodnih radikala (hidroksil-radikala $\bullet O H$ ), koji mogu da pretrpe sekundarne reakcije. Praktična primena fotokatalize omogućena je otkrićem postupka elektrolize vode pomoću titanijum-oksida. Krajnji cilj dizajna fotokatalizatora je da se olakšaju reakcije pobuđenih elektrona sa oksidantima kako bi se dobili redukovani produkti, i/ili reakcije šupljina sa reduktantima $u$ cilju stvaranja oksidovanih produkata.

2.4. TiO2- Titanijum dioksid je prirodan oksid titanijuma, čija je formulaTiO $\mathrm{T}_{2}$. Među nanomaterijalima jedan je od najproizvedenijih i najšire korišćenih u svetu.Heterogene fotokataličke reakcije sa $\mathrm{TiO}_{2}$ kao fotokatalizatorom su veoma često upotrebljavani procesi za rešavanje problema u životnoj sredini, uključujući prečišćavanje vode i vazduha. Velika primenljivost $\mathrm{TiO}_{2}$ je posledica njegove biološke $\mathrm{i}$ hemijske inertnosti, nije foto $\mathrm{i}$ hemijski korozivan i jeftin je.

2.5. ZnO- Cink oksid spada u grupu poluprovodničkih oksidnih materijala sa velikom energijom procepa pri ambijentalnim uslovima usled čeka molekuli $\mathrm{ZnO}$ mogu apsorbovati samo zračenje iz UV oblasti spektra.Velika energija pobuđivanja veze u molekulu $\mathrm{ZnO}$ omogućava efikasnu ekscitonsku rekombinaciju na sobnoj temperaturi. Cink oksid je beli praškasti materijal neorganskog porekla koji je u prirodi veoma rasprostranjen. Pokazuje veoma malu rastvorljivost u vodi i alkoholu, dok se potpuno rastvara u minerlnim kiselinama i bazama. Tokom zagrevanja boja $\mathrm{ZnO}$ se menja od bele do žute a tokom procesa hlađenja se ponovo vraća u belu.

Cink oksid se kristališe $u$ tri forme: heksagonalna vurcitna, kubna svaleritska i kubna natrijum-hloridna.

$\mathrm{ZnO}$ ima veliku primenu u sistemu zaštite životne sredine zbog svojih osobina kao što je širina energetskog koja omogućava apsorpciju zračenja u bliskoj UV oblasti, zatim jaka moć oksidacije i dobre fotokataličke osobine.

\section{FOTOKATALITIČKA RAZGRADNJA NAPROKSENA MEŠAVINOM $\mathrm{ZnO} / \mathrm{TiO}_{2}$ NANOČESTIČNOG PRAHA}

Fotokatalitička razgradnja naproksena izvedena je na sobnoj temperaturi u vodenom rastvoru u serijskom režimu. Osnovni rastvor analiziranog leka je pripremljen rastvaranjem $5 \mathrm{mg}$ standarda u $25 \mathrm{mg}$ acetonitrila (200 $\left.\mathrm{mgL}^{-1}\right)$.

Destilovana voda je korišćena kao vodeni model. Vodeni rastvor je mešan $1 \mathrm{~h}$ u mraku da bi se uspostavila adsorpciono-desorpciona ravnoteža između naproksena i fotokatalizatora pre nego što je zračenje. Početna koncentracija naproksena bila je $4,5 \mathrm{mgL}^{-1}$. Vodeni rastvori $30 \mathrm{mg}$ katalizatora u $50 \mathrm{ml}$ vode izloženi su kontinuiranom UV zračenju.

Izvor UV svetlosti bila je živa lampa visokog pritiska snage $125 \mathrm{~B}$. Rastvori su mešani uz pomoć magnetne mešalice pri $130^{\circ} / \mathrm{min}$. Da bi se istražila promena ispitivanog zagađivača sakupljene su alikvote u određenim vremenskim trenucima $(5,10,20,30,40,50$ и 70 min). Svaki uzorak je filtriran kroz filter papir kako bi se odvojio $\mathrm{TiO}_{2}$ / Zno nanočestice od rastvora.

Nakon koraka filtracije, $1 \mathrm{ml}$ uzorka je preneto u $2 \mathrm{ml}$ bočice. Za merenje koncentracije NPX nakon fotokatalize degradacije korišćena je HPLC (tečna hromatografija visokih preformansi) sa diodnim detektorima.

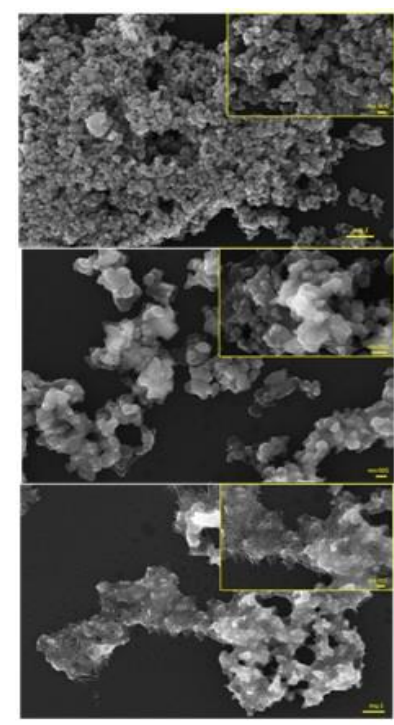

Slika 1. Reprezentativne FE-SEM slike $\mathrm{TiO}_{2}, \mathrm{ZnO}$ i smeše $2 \mathrm{ZnO}-\mathrm{TiO}_{2}[2]$. 


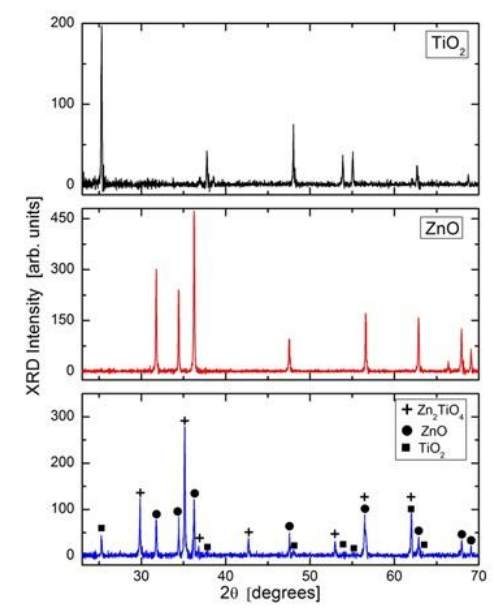

Slika 2. XRD snimak čistih i mešanih nanočestica $2 \mathrm{ZnO}-\mathrm{TiO}_{2}$ [2]. Tri faze u donjem panelu označene odgovarajućim simbolima

Slika 1 pokazuje da $\mathrm{TiO}_{2}$ čestice karakteriše globularni oblik sa prosečnom veličinom čestica $100 \mathrm{~nm}$, dok čestice $\mathrm{ZnO}$ predstavljaju složenije oblike gdeigličasti oblici (nanoiglice) dominiraju nad česticama nepravilnih oblika. Čini se da smeša zadržava morfološke karakteristike $\mathrm{TiO}_{2}$.

Strukturna karakterizacija urađena je metodom XRD (slika 2.)

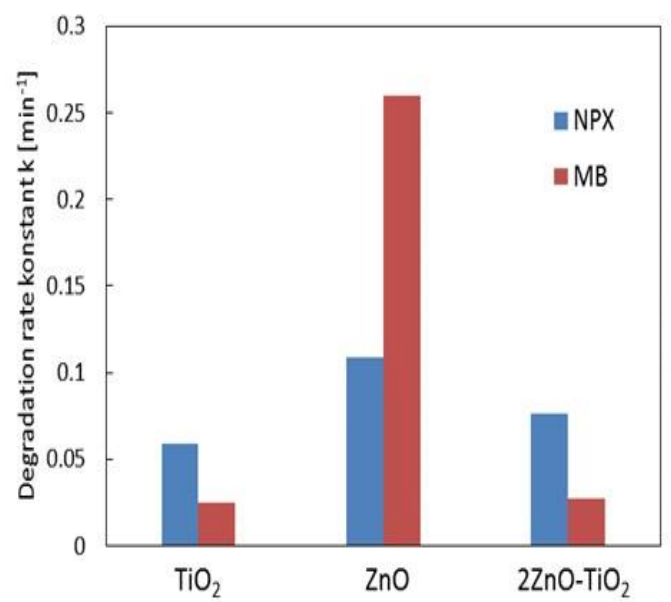

Slika 3. Upoređivanje konstantne brzine k za fotodegradaciju MB (metilen blue boje) i NPX pod UV zračenjem na nanočestice $\mathrm{ZnO}, \mathrm{TiO}_{2}$ i $2 \mathrm{ZnO}-\mathrm{TiO}_{2}$ [2]

Prah $\mathrm{ZnO}$ pokazuje veću efikasnost u potodegradaciji NPX, u poređenju sa $\mathrm{TiO}_{2}$ i smeše $2 \mathrm{ZnO}-\mathrm{TiO}_{2}$. Slična dominacija $\mathrm{ZnO}$ u smislu fotodegradacije uočena je i kod fotodegradacije drugog organskog polutanta, boje metilen blue MB (slika 3) [2].

\section{PITANJE UTICAJA PRIMENE ZnO i TIO2 NA ŽIVOTNU SREDINU}

Povećana proizvodnja i upotreba sintetičkih nanočestica dovodi do veće verovatnoće za njihovo ispuštanje $u$ životnu sredinu i izloženost organizama. Nanočestice u okolini mogu da ostanu u suspenzijama kao pojedinačne česice, ili kao agregati, formirajući veće čestice ili čak taloge; mogu da se apsorbuju se na vodenim sastojcima, transformišu se hemijski ili biološki u vodenom okruže- nju. Istraživanja iz oblasti interakcija nanočestica još uvek su u početnoj fazi, ali postoje jasne indicije da nanočestice mogu imati značajan negativni uticaj na akvatične ekosisteme [3-6]. U tom smislu, potrebna su detaljna i opsežna istraživanja na ovu temu pre komercijalne upotrebe nanokatalizatora za prečiščavanje otpadnih voda.

\section{ZAKLJUČAK}

U ovom radu je ispitivana fotokatalitička degradacija nesteroidnog antiinflamatornog analgetika i antipiretika naproksena (NPX), za koga je ustanovljeno se ubraja među najperzistentnije farmaceutske polutante $\mathrm{u}$ površinskim vodotokovima, primenom $\mathrm{ZnO} / \mathrm{TiO}_{2}$ heteronano-struktura kao katalizatora. Pri tome je najpre eliminisan uticaj adsorpcije na razgradnju naproksena. Efikasnost degradacije ustanovljena je merenjem promene njegove koncentracije i efikasnosti dekompozicije u zavisnosti od vremena razgradnje pri uslovima optimalne osvetljenosti i na sobnoj temperaturi.

Potom je eksperiment uradjen u mraku i pod dejstvom ultraljubičastog zračenja, pri čemu je konstatovano da $\mathrm{ZnO} / \mathrm{TiO}_{2}$ poseduje izrazite fotokatalitičke sposobnosti. Ovi rezultati ukazuju na opravdanost kombinovanja cink oksida sa titanijum dioksidom fotokatalitičkog procesa razgradnje naproksena i otvaraju perspektivu da se nekim drugim mešavinama ovi rezultati mogu i poboljšati.

Ono što ostaje kao glavni cilj u narednim istraživanjima procesa heterogene fotokatalize jeste pronalaženje materijala ili kombinacije materijala koji bi ispoljavali fotokatalitičku aktivnost i pri uslovima optimalne osvetljenosti (vidljiva svetlost, Sunčeva ili veštačka), kao i ispitivanje potencijalnih negativnih efekata novih nanočestica na životnu sredinu, posebno na akvatične sisteme.

\section{LITERATURA}

[1] Küster, A., Adler, N., Pharmaceuticals in the environment: Scientific evidence of risks and its regulation. Philos. Trans. R. Soc. B Biol. Sci. 369. doi:10.1098/rstb.2013.0587, 2014.

[2] Strbac D., Aggelopoulos C., Strbac G., Dimitropoulos D., Novakovic M., Ivetic T., Yannopoluos S., Photocatalytic degradation of Naproxen and methylene blue: Comparison between $\mathrm{ZnO}$, $\mathrm{TiO} 2$ and their mixture, Process Safety and Environmental Protection, 2018.

[3] Aruoja V, Dubourguier HC, Kasemets K, Kahru A. (2009). Toxicity of nanoparticles of $\mathrm{CuO}, \mathrm{ZnO}$ and $\mathrm{TiO}_{2}$ to microalgae Pseudokirchneriella subcapitata. Sci Total Environ., 2009

[4] Bausch J. M, Connors K. A, Brooks B. W, Rand G. M., Human pharmaceuticals in the aquatic environment: a review of recent toxicological studies and considerations for toxicity testing. Rev. Environ. Contam. Toxicol., 2012.

[5] Wu,J. Sun, J. and Xue, Y., Involvement of JNK and P53 activation in G2/M cell cycle arrest and apoptosis induced by titanium dioxide nanoparticles in neuron cells,” Toxicology Letters, 2010. 
[6] Xie Y, He Y, Irwin P L, Jin T, Shi X., Antibacterial activity and mechanism of action of zinc oxide nanoparticles against Campylobacter jejuni. Applied and Environmental Microbiology, 2011.

\section{KRATKA BIOGRAFIJA:}

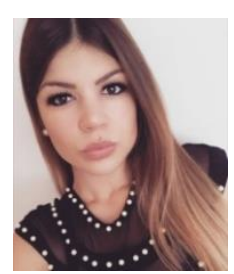

Vanesa Distl rođena je u Subotici.

$\mathrm{Na}$ fakultetu Tehničkih nauka na smeru

Inženjerstvo zaštite životne sredine diplomirala je 2017.godine, a Master rad je odbranila 2019. Godine.

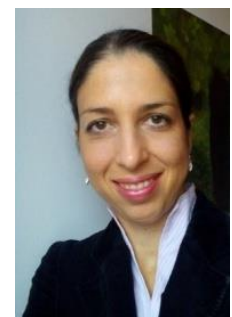

Dr Dragana Štrbac, vanredni profesor na Fakultetu tehničkih nauka u Novom Sadu, na Katedri za Inženjerstvo zaštite životne sredine. Koautor je 24 rada sa SCI liste i 77 drugih radova i saopštenja. 